Шуст, Людмила. «Семантико-стилістичні особливості вигуків у драмі-феєрії Лесі Українки “Лісова Пісня"». Лінгвостилістичні студії, вип. 14, 2021, с. 155-63.

Shust, Liudmyla. "Semantic and Stylistic Features of Exclamations in the Drama-Fairy-Tale "The Forest Song" by Lesia Ukrainka". Linguostylistic Studies, iss. 14, 2021, pp. 155-63.

УдК 81'37:81'3:81'367.628:821.161.2Українка(477.82)

https://doi.org/10.29038/2413-0923-2021-14-155-163

\title{
СЕМАНТИКО-СТИЛІСТИЧНІ ОСОБЛИВОСТІ ВИГУКІВ У ДРАМІ-ФЕЄРІЇ ЛЕСІ УКРАЇНКИ «ЛІСОВА ПІСНЯ»
}

\author{
Людмила Шуст \\ Комунальний заклад вищої освіти «Луцький педагогічний коледж» \\ Волинської обласної ради, Луцьк, Україна
}

У статті проаналізовано інтер'єктиви, використані Лесею Українкою в «Лісовій пісні», визначено їх семантико-стилістичні особливості. Виявлено, що одними 3 найпродуктивніших $€$ первинні емоційні вигуки, які часто надають емоційного забарвлення всій репліці. Проаналізовано семантику інтр'єктивів, що виконують комунікативно-волюнтативну функцію. Зафіксовано ряд дієслівно-вигукових форм, особливістю яких є відображення миттєвої, короткочасної дії. Звернуто увагу на вигуки мовного етикету, а також вигуки-божіння та вигуки-прокльони. божіння.

Ключові слова: інтер'єктив, семантика, первинні емоційні вигуки, прокльони,

\section{SEMANTIC AND STYLISTIC FEATURES OF EXCLAMATIONS IN THE DRAMA-FAIRY-TALE “THE FOREST SONG” BY LESIA UKRAINKA}

\author{
Liudmyla Shust \\ The Municipal Higher Educational Institution "Lutsk Pedagogical College" \\ of the Volyn Regional Council, Lutsk, Ukraine
}

Exclamations are a special class of words that express emotionally-expressive reactions, evaluations, expressions of will, without naming them. Depending on the context, they can acquire different semantic and stylistic possibilities.

The interactives used by the authors in the fictional texts are particularly significant. Firstly, their use testifies to the affinity of works with living colloquial speech, and secondly, the writer can provide exclamations with a special semantic content, introducing them into neutral contexts. The language of Lesia Ukrainka's drama-fairy-tale "The Forest Song" is analyzed in the article and the semantic and stylistic features of exclamations in it are determined.

The language analysis of the text showed that the exclamations in the lines of the characters are used quite often and appropriately. They emphasize the emotional state of the character, give it an evaluative characteristic, reflect the dialectal features of local dialects.

The study has revealed that one of the most productive exclamations is the primary emotional exclamations " $o$ ", "oh", "oy", which often add emotional colour to the whole line. The semantics of interactives that play a communicative-voluntary function is analyzed.

(C) Шуст Л., Волинський національний університет імені Лесі Українки, 2021.

Це стаття відкритого доступу на умовах СC BY-NC 4.0 
A number of verb-exclamation forms have been recorded, the peculiarity of which is the reflection of instantaneous and short-term action. Attention is paid to the exclamations of language etiquette, exclamations-oath, and exclamations-curses.

Fixed interjections are divided into nine subgroups: emotional-evaluative, affective, vocative, negative, reflexive, imperative (commanding, motivating, appealing), etiquette, exclamations-curses, exclamations-oath. The most productive exclamations are emotionalevaluative and imperative.

Exclamations play an important role in the speech of literary characters, as they help the author to convey more deeply and fully the worries, emotions and character traits of a hero.

Key words: interactive, semantics, primary-emotional exclamations, curses, oaths.

Вступ. Вигуки - особлива частина мови. Це один із найдавніших класів слів, однак його дослідження й донині лишається найбільш спорадичним в українській лінгвістиці.

Специфіка вигуків - виражати емоційно-експресивні реакції, оцінки, волевиявлення, не називаючи їх, - апріорно визначає стилістичні можливості цього класу слів, бо в такому разі емоційне забарвлення органічно входить у семантичну структуру вигуку як мовної одиниці (Мацько, «Стилістичні функції»).

Як реченнєві одиниці, що $є$ узагальнено-усвідомленими мовними знаками, вигуки передають надзвичайно широкий спектр емоцій i почуттів, які створюються не самими вигуками, а контекстуальним оточенням і відповідною інтонацією (Жагаляк 26).

У живому мовленні вони безпосередньо пов'язані з темою і змістом інформації, емоціями, оцінками, настроями мовців і передаються з певною інтонацією, мімікою і жестами. У цьому комунікативному комплексі вигук сприймається слухачем як мовленнєва одиниця з певним значенням, у тому числі й стилістичним (Мацько, «Стилістичні функції»).

Дослідженням вигуків як специфічного мовного явища займалися українські та зарубіжні вчені ще з минулого століття. Так, О.Потебня розвиває ідею вигукового походження мови. Ш.Баллі та Л. Теньєр розглядають походження та семантику вигуків. Дослідники другої половини XX ст. (О. Германович, В. Косов, А. Колодяжний, К. Городенська) намагаються переважно класифікувати традиційні вигуки, не враховуючи функціонального аспекту досліджуваних одиниць (Мельник 198-9). Л. Мацько розробляє окрему семантичну класифікацію для первинних вигуків (Мацько, Інтер'єктиви).

Особливої уваги, на нашу думку, заслуговують інтер'єктиви, використовувані авторами в художніх текстах. 3 одного боку, їх уживання засвідчує спорідненість творів із живим народним мовленням, з іншого ж, письменник може надавати вигукам особливого семантичного наповнення, вводячи їх в нетипові контексти.

Мета роботи - дослідити мову драми-феєрії Лесі Українки «Лісова пісня» та визначити семантико-стилістичні особливості вигуків у ній. 
Матеріал і методи дослідження. Матеріалом дослідження є текст драми-феєрії «Лісова пісня», зокрема інтер'єктиви, ужиті там. Під час роботи було використано типологічний метод (для виокремлення семантичних груп), лінгвогенетичний метод (для уточнення семантики окремих лексем), метод кількісних підрахунків (для аналізу якісних і кількісних характеристик інтер'єктивів).

Результати дослідження та дискусія. Вигуки, як засоби вираження почуттів, емоцій, а не називання їx, $\epsilon$ одиницями багатозначними i узагальненими. Реальне значення їх розкривається тільки в ситуації усного мовлення відповідною інтонацією та додатковими кінетичними (руховими) засобами (мімікою, жестами) (Мацько, «Стилістичні функції»). Особливості вигуків, уживаних у художніх творах, визначаються контекстом, авторським задумом щодо конкретного персонажа чи бажанням максимально точно передати автентичність місцевої говірки. На думку Л. Мацько, у художньому тексті вигуки $\epsilon$ не тільки засобом передачі емоційної характеристики героїв, їх ставлення до навколишнього світу, а й показником авторської симпатії щодо оцінки героїв (Мацько, «Стилістичні функції»).

Аналіз мови драми-феєрії Лесі Українки «Лісова пісня» засвідчив, що вигуки в репліках героїв ужиті досить часто й доречно, підкреслюють емоційний стан персонажа, додають йому оцінної характеристики, відбивають діалектні особливості місцевих говірок.

Продуктивними в досліджуваному тексті $€$ первинні емоційні вигуки $\boldsymbol{o ,}$ ox, ой, які часто надають емоційного забарвлення всій репліці. Інтер'єктив о виражає здивування: $\boldsymbol{O}$, квіти на личеньку одразу зацвіли! цнотливії, незапашні, осінні... (Українка 305); о! тепер вже сиві, як тая хмара... (Українка 256-257) Семантика вигука ой, за нашими спостереженнями реалізується так: 1) здивування, захоплення: Ой! Що се за сопілка? Чари! Чари! (Українка 323); 2) несподіванки: Ой, зачепилася за дуб торішній! (Українка 249); 3) смутку, заперечення: Ой, не сягає! (Українка 278). Останнє значення використано найчастіше, причому вигук ой підсилюється лексемою з негативною конотацією: Ой горенько! косо моя! косо моя золотая! Ой лишенько! красо моя! красо моя молодая!.. (Українка 292); Ой лишенько! Іще не починала! Ой мій упадоньку! Що ж ти робила? (Українка 294); Ой лихо! Я боюся притулятись, а так не встою (Українка 272); Ой леле! не нуртуй! Хатинки не руйнуй! (Українка 244); Ой лелечко! То се тут люде будуть? (Українка 590); Ой горе! Хто б говорив! (Українка 320); Ой горе! Якось треба ратуватись... (Українка 326); Ой, тепер я плачу, бо вже чую й бачу (Українка 327). Примітно, що І. Жагаляк вигук ой розглядає як афективний, тобто такий, що в реальному мовленні вирізняється абсолютною відсутністю експресивності (Жагаляк 29). Однак ця думка не знаходить підтвердження в тексті Лесі Українки, де інтер'єктив ой виразно емоційно забарвлений. Часто вигук ой супроводжує звертання: ой дядьку, ой нене, ой мамо, ой тітко, ой дядинусю, ой любчику, ой синоньку, ой чоловіче. 
До афективних вигуків зараховуємо ху (Ху, душно як! (Українка 250)). Він абсолютно не залежить від емоційного стану героя, бо супроводжує фізичний. Дослідники ще називають такі інтер'єктиви рефлекторними, оскільки ті використовуються для позначення фізіологічного стану чи реакції організму на подразнення (кашель, позіхання, плач, дихання, нестримний сміх тощо) і не впливають на реципієнта. Напр., Xa-xa-xa! He знаю! Попитай у гаю (Українка 266); Русалка. Ха-ха-ха! (3 сміхом і плеском кидається в озеро) (Українка 272). Виявлено, що спорадично такі вигуки можуть переходити в розряд емоційних, відповідно повертаючи собі емотивну та експресивну функції, які реалізуються залежно від ситуації:

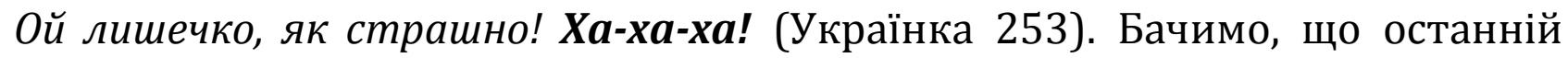
вигук ужитий штучно, щоб виразити ставлення до сказаного перед тим.

Вигук ох у репліках героїв «Лісової пісні» зазвичай мимовільний, має позитивне емоційне забарвлення, виражає задумливість, замріяність: Ох!.. Зірка в серце впала (Українка 272); Ох, як я довго спала! (Українка 254); 0x, торішнє літо так давно минуло! (Українка 265).

Проаналізуємо інтр'єктиви, що виконують комунікативно-волюнтативну функцію. Частовживаним у «Лісовій пісні» $\epsilon$ вигук ей. Його зараховуємо до заперечних інтер'єктивів, котрі за своїм значенням співвідносні із заперечною часткою «ні», однак семантика заперечення у них виражена слабше, ніж у відповідних часток, вона прихована у контексті і визначається ним (Жагаляк 31). Досліджуваний текст підтверджує цю думку. Вигук ей ужитий або в реченнях із запереченням (Ей, ні вже, дядинусю, я піду (Українка 299); Ей, не пора мені тепера грати! (Українка 290); Ей, хлопче, вже моє грання минулось!.. (Українка 322) ), або ж як апелятив до співрозмовника для привернення уваги (Eй! не вчись брехати, бо ще ти молодий! (Українка 267); Ей, кодло лісове! Така в вас правда!.. (Українка 279); Ей, одчепися! (Українка 317); Ей, Злидні, залишіть то не людина (Українка 314) ). Із протилежним значенням вжито вигук еге ж - як ствердження, наполягання, переконання: Еге ж, тоді ти в морі... (Українка 248); Eге! то знаю ж я! (Українка 280).

Вигук гей зазвичай використаний біля звертання (Гей, дубоньку, чи будеш ти стояти, як сива голова моя схитнеться?.. (Українка 298) ) або ж заміняє повноцінне звертання, коли адресат не знайомий (Гей, слухай, чи ти п'яна, чи, може, змерзла? (Українка 316) ).

Вигук ну (ну-ну, ану) активно вживаний на Західному Поліссі (мовлення та звичаї саме цього регіону лягли в основу «Лісової пісні»). Зазвичай виражає спонукання, заклик до дії: Ну, то хоч раз послухай - не завадить (Українка 285); Ну, розчеши, я сам люблю порядок (Українка 248); Ну, не глузуй! (Українка 264); Ну, жніте ж, дітоньки, а я піду звару вам киселиці на полудень (Українка 294); Ну ж, парубче, хутчій! Не лізь, як слимак! (Українка 295); Ну, то скажи йому, як має звати, - уже ж не дядьком? (Українка 321); Ану ж, ану! Що хто кого - побачим! (Українка 295). Може підсилювати семантику питальних речень: Ну, а куди ж тоді 
відьомська пара подінеться? (Українка 286); Ну, скілько ж [їх] там? калинова, вербова та липова - ото й усі (Українка 588); Ну, що се значить «накинулась»? (Українка 290); Ну, то чого ж прийшла тут наглядати, коли не хочеш помогти? (Українка 296). Спорадично використовується як знак закінчення розмови, маркер останнього речення: Ну-ну, чекайте ж, приведу я взавтра щеняток-ярчуків, то ще побачим, хто тут заскавучить! (Українка 280); Ну, мир миром! Поплинем понад виром! (Українка 280); Нy, я піду, а ти собі як хочеш (Українка 252); Ну, я піду - управлюся тим часом 3 дробиною (Українка 280); Ну, будьте вже здоровенькі, тітусю! (Українка 286). Може містити семантику застереження: Ну-ну, помалу! (Українка 314); Ну-ну, тапер недовго настоїшся!.. (Українка 317).

Окремо виділяємо інтер'єктиви, використовувані в небезпечній ситуації, щоб покликати на допомогу (пробі): Пробі! Гину! В дряговину попав! (Українка 278), а також для встановлення зв'язку із людиною на значній відстані (напр., у лісі): гов: Гов, Лукашу, гов! го-го-го-го! А де ти? (Українка 263); Лукашу, гов! А де ти? (Українка 283). Такі вигуки вважають апелятивними.

Вигук бач (ба, чи ба, ба ні) використано переважно для привернення уваги, може виражати здивування: Бач! умалився!.. (Українка 268); бач, вона така суха, і все рипить, все згадує про зиму... (Українка 262); Бач, підсилає своїх дівок, а сам - і я не я! (Українка 280); Бач, я тебе за то люблю найбільше, чого ти сам в собі не розумієш (Українка 289); тепер, бач, навіть сонце прохололо (Українка 304); Чи ба! Я в добрий час тобі сказала! (Українка 317); Hi... стій... ба! Чуєш?.. То весна співає? (Українка 254); Ба, то вже судилось відьомською свекрухою вам бути (Українка 320); Ба! так би ти й казав, то я ж би знав! (Українка 279); як дівчина... ба ні, хутчій як панна (Українка 256). Зафіксовано випадок, коли вигук ба в контексті вжито в значенні 'дарма': Я відаю, кого ти дожидаєш, та тілько ба! - шкода твого ждання! (Українка 320). Такі інтер’єктиви І. Жагаляк вважає заперечними, оскільки «вони містять у собі семантику емоційного заперечення і при умові зниження емоційного навантаження можуть бути замінені іншою частиною мови з часткою “не” або однією заперечною часткою "ні"» (Жагаляк 30).

Інтер'єктиви $\boldsymbol{a}, \boldsymbol{a z a}, \boldsymbol{a u ̆ , ~ e m , ~ о в в а , ~ о г о - г о ~ в ж и т і ~ с п о р а д и ч н о . ~ В о н и ~}$ зазвичай виражають здивування, сумнів, іронію та інші емоції залежно від контексту: A, от ти хто! (Українка 256); Ай, дай спокій! (Українка 287); Aгa, то ти? (Українка 296); Em, таке питаєш!.. (Українка 257); Я 6 то? боявся в лісі? Ого-го! помалу! (Українка 299); Овва! Коби всії біди! Яка скупа (Українка 252); Овва! А батько мій їх всіх потопить! (Українка 253).

Двічі у драмі-феєрії використано вираз цур-пек: Поки дійдем, ще й тая нападе - не тута споминаючи, цур-пек! (Українка 267); Вже знов якась мара? Цур-пек! щезай! (Українка 279). Цур і Пек, за язичницькими віруваннями наших предків, були хатніми охоронцями, що захищали від ворогів, допомагали їх спекатися, відцуратися. Тому й уживалися вказані 
паремії людиною в небезпечних, на ії думку, ситуаціях. У примітках до цитованого видання творів Лесі Українки також зазначено: «Водночас $\epsilon$ версія, що це божества-антагоністи: Цур (Чур) - добрий бог домашнього вогнища, добробуту, а Пек - божество сварок і кривавих сутичок. У магічному заклятті зловорожі дії одного нейтралізувалися силою другого» (Українка 609).

Зафіксовано ряд дієслівно-вигукових форм. Їхня особливість у тому, що вони не виділяються комами та $\epsilon$ членами речення (зазвичай присудками). На думку О. Тодор, у розмовному стилі ці слова $\epsilon$ природнішими, ніж їхні дієслівні еквіваленти, оскільки жваво, влучно передають динаміку подій (Тодор). У «Лісовій пісні» ці одиниці функціонують зі значенням:

1) стояти, зупинитися: а він вчепився иупко лапою за днище, та й $\boldsymbol{a н \boldsymbol { i }}$ руш! (Українка 266); Лукашу!.. Ані руш! Чи остовпів? (Українка 324); Cтій! не квапся (Українка 253);

2) мовчати, затихнути: Цить!.. Бо знову прилетить (Українка 272); Цить! Хай говорить серце... (Українка 274); Цить! почують мати! (Українка 290);

3) втікти, пропасти: Далі - вже моя робота! Ну! блись-блись! (Українка 277); А тут іще й тебе щось учепило, - кричу, гукаю, кличу - хоч ти згинь! (Українка 267);

4) проганяти: Геть! не глузуй! (Українка 304); Геть! Щезайте! Ніхто не кликав вас! (Українка 313); Геть! не мороч мене! Чого стоїш? (Українка 317);

5) смикнути, штурхнути: Та проклята ж пара - штурхіць! - $i$ перекинула човна! (Українка 267).

Особливістю таких форм є відображення миттєвої, короткочасної дії.

Спорадично в ролі інтер'єктивів ужиті повнозначні лексеми, зокрема іменники, дієслова: Мати Лукашева і Килинині діти вибігають з хати 3 криком: «Горить! Горить! Ратуйте! Ой пожежа!..» (Українка 324); Дідусю! Лісовий! біда! ратуйте! (Українка 252). Виражаючи людські почуття, такі абстрактні іменники, як пожежа! біда! абсолютно передбачено виявляють здатність до інтер'єктивації (Глібчук 141).

Вигуки мовного етикету, зафіксовані в досліджуваному тексті, можемо поділити на три групи:

1) традиційні словесні формули привітання/прощання: Будь здорова, дівко! (Українка 281); Ходімо. Прощавай! (Українка 281); Добридень, дівонько! (Українка 294);

2) специфічні західнополіські вирази, що супроводжують процес праці в полі: Лукаш (виходить; до Килини) Магайбі. Килина (жнучи) Дякувати (Українка 294). Завважимо, що відповідь дякувати (дієслово у формі інфінітива) - нетипова для Західного Полісся. Очевидно так авторка хотіла підкреслити зверхність, удавану байдужість Килини до залицяльника. 
3) створені авторкою римовані фрази, схожі на народні: Живі бувайте, нас не забувайте!; Веселі будьте, та до нас прибудьте! (Українка 300).

Н. Глібчук вважає, що дієслівні словоформи способу (наказ.) особи (2-ої), числа (одн., мн.) втрачають здатність змінюватися, немов «застигають», позбувшись морфологічних і синтаксичних ознак дієслова, втрачають частиномовне значення процесуальності, натомість набувають значення інтер'єктивності (146). Тобто дослідниця зараховує їх до вигуків, наводячи, зокрема, приклад із «Лісової пісні»: Коли б ти, нічко, швидче минала! Вибач, коханая! Ще ж я не знала днини такої, щоб була щасна так, як ти, ніченько, так, як ти, ясна! (Українка 281). Не можемо погодитися 3 цією думкою, оскільки немає підстав вважати, що виділена лексема справді позбулася морфологічних і синтаксичних ознак дієслова. У цьому контексті слово вибач має відповідні граматичні ознаки числа й особи, що й підмет у попередньому реченні.

Як було зазначено вище, в основу «Лісової пісні» покладено традиції та мовлення поліщуків. Відомо, що на цій території поширеним $\epsilon$ використання вигуків-божінь у побутовому мовленні (див. про це (Шуст)). У творі ця традиція збережена. Вигуки-божіння мовці використовують переважно для підтвердження власного вислову, особливо тоді, коли співрозмовник сумнівається в почутому. Це - мовленнєві фрази, які не потребують, щоб хтось на них відповідав, хоча звернені до конкретної особи. Вигук бігме утворений лесико-синтаксичним способом від іменника Біг (Бог) і скороченої форми займенника мене чи мені на грунті усталених виразів типу Бог мене побий/покарай або Бог мені допоможи (Етимологічний словник 191): Ну, й я не дурень, як засяг рукою за бороду, то й замотав, як мичку, та ножика з-за пояса, - Бігме, так і відтяв би! (Українка 266-267); Вона мене поратувала, дядьку, от Бігме згинув би тепер без неї! (Українка 280); Ви хочете, щоб я не тілько з хати, а з світа геть зійшов? Бігме, зійду! (Українка 281). Звертаємо увагу, що в автографі твору цей вигук завжди вживаний з великої літери.

Розуміння Бога як Творця, вірування в Його всемогутність виявляється в божіннях дасть Біг і простибіг: Вже якось сама управлюся, а там на вісень, дасть Бі2, знайду собі невістку в поміч (Українка 291); Таке воно, простибіг, ні до чого... (Українка 293).

Специфічних комунікативних рис у контексті побутування вигукових фразеологічних формул набирають вигуки-прокльони, тобто побажання, що містять негативні емоції (Чабаненко 200). На думку Ю. Дем'янової, $з$ часом негативні волюнтативи, втративши своє магічне значення, почали вживатися як засіб вираження вербальної агресії (176): Той клятий Водяник! Бодай би всох! (Українка 266); Я ледь що вибрався живий на берег, і рибу розгубив... A, щоб ти зслиз! (Українка 267).

У тексті «Лісової пісні» частково знаходимо підтвердження думки С. Пушика, письменника-збирача негативних висловів, про те, що таким нетолерантним способом комунікації послуговуються «найчастіше 
одинокі, чимось ображені жінки. У такий спосіб вони намагаються захистити свою хату, своє гніздо від недоброзичливості зовнішнього світу» (Крайній): Килино! Гей, Килино! Ну, та й спить же! Бодай навік заснула... Встань! А встань, бодай ти вже не встала! (Українка 314). Бачимо, однак, що героїня відчуває небезпеку не стільки від зовнішнього світу, скільки всередині власної родини, у своїй же хаті. Така ситуація найчастіше й породжує багато прокльонів та магічних волюнтативів (згадаймо також хрестоматійну повість I. Нечуя-Левицького «Кайдашева сім'я» і залежність комунікативної ситуації від стосунків у родині).

Окремо хочемо виділити вирази застереження: Бийся по губі! Що се ти говориш? (Українка 324); Який би чоловік з тобою всидів? Бідо напрасна! (Українка 315); Нехай не важсться! Бо завалю все озеро гнилим торішнім листом! (Українка 253). У таких конструкціях немає явної загрози, однак їхній зміст та оклична інтонація свідчать про небажаність, небезпечність ситуації.

Аналіз семантичних груп інтер'єктивів у «Лісовій пісні» дозволяє стверджувати, що найуживанішими в тексті $\epsilon$ емоційно-експресивні (60 одиниць) та імперативні вигуки (57 од.), що виражають наказ (11 од.), спонукання до дії (3 од.) або ж апелюють до співрозмовника (43 од.). Вокативні вигуки представлені 7 одиницями, лайливі - 9, мовного етикету 7, божіння - 5, рефлекторні (афективні) - 4. Тож загалом у тексті виявлено 149 інтер'єктивів.

Висновки та перспективи досліджень. У художній літературі інтер'єктив часто використовується як стилістичний засіб для підкреслення надмірної чи вдаваної чутливості, манірності, сентиментальності тощо. Тому й уживані зазвичай емоційно-експресивні вигуки. Аналіз вказаних лексичних одиниць у драмі-феєрії Лесі Українки «Лісова пісня» довів, що їх використання не є штучним. Інтер'єктиви повніше й глибше відображають переживання, емоції героїв. Широковживаними виявилися імперативні вигуки. Це дозволяє стверджувати, що на Західному Поліссі звертання до співрозмовника чи прохання супроводжувалося зазвичай вигуком. Перспективними вважаємо дослідження мови творів авторів 3 інших регіонів щодо використання інтер'єктивів і вплив цієї лексичної групи на семантику тексту.

\section{Список використаної літератури}

Балли, Шарль. Общая лингвистика и вопросы французского языка. Москва: Издательство иностранной литературы, 1955.

Глібчук, Наталія. «Синкретична природа похідних інтер'єктивів у площині міжчастиномовної омонімії». Вісник Львівського університету. Серія філологічна, вип. 64(1), 2017, с. 138-50.

Дем'янова, Юлія. «Волюнтативи 3 негативною семантикою. Лінгвокультуроогічна інтерпретація мотивів і образів». Вісник Запорізького національного університету. Філологічні науки, № 1, 2010, с. 173-9.

Етимологічний словник української мови, під ред. О. С. Мельничука. В 7 т. Т. 1. Київ: Наукова думка, 1982. 
Жагаляк, Ірина. «Семантичні особливості інтер'єктивів». Studia Methodologica, вип. 13, 2003, с. 26-33.

Крайній, Іван. «Інтерв'ю з С. Пушиком». Україна молода, вип. 106, URL: https://www.umoloda.kiev.ua/number/936/164/34070.

Мацько, Любов. Інтер'єктиви в українській мові. Київ, 1981.

Мацько, Любов. Стилістичні функції емоційних вигуків. URL: http://kulturamovy.univ. kiev.ua/KM/pdfs/Magazine21-5.pdf.

Мельник, Олена. «Первинні вигуки як об’єкт лінгвістичного дослідження». Мова $i$ культура, вип. 16, т. 5, 2013, с. 196-204.

Потебня, Александр. Эстетика и поэтика. Москва : Искусство, 1976.

Теньер, Люсьен. Основы структурного синтаксиса. Москва: Прогресс, 1988.

Тодор, Олена. Про дієслівно-вигукові форми в українській мові. URL: http://kulturamovy.univ.kiev.ua/KM/pdfs/Magazine45-18.pdf.

Українка, Леся. «Лісова пісня». Повне академічне зібрання творів. У 14 т. Т. 3. «Драматичні твори». Луцьк, 2021, с. 241-329.

Чабаненко, Віктор. Стилістика експресивних засобів української мови. Запоріжжя, 2002.

Шуст, Людмила. «Вигуки-божіння як особливість сакральної культури українців». Науковий вісник Чернівецького університету. Романо-слов'янський дискурс, вип. 772, 2016, с. 156-8.

\section{References}

Bally, Charles. Obshhaja lingvistika i voprosy francuzskogo jazyka. Moskva: Izdatel'stvo inostrannoj literatury, 1955.

Glibchuk, Nataliya. "Syncretic Nature of Derivative Intejections as a Part Oflexico-grammatical Homonymy". Visnyk of Lviv University. Series Philology, iss. 64(1), 2017, pp. 138-50.

Demianova, Yuliia. "Negative Wishes. Lingvistic and Culturological Interpretation of Motives and Images". Zaporizhzhia National University Bulletin. Philology, 2010, № 1, pp. 173-9.

Etymolohichnyi slovnyk ukrainskoi movy, edited by 0. S. Melnychuk. 7 vols. Vol. 1. Kyiv: Naukova dumka, 1982.

Zhahaliak, Iryna. "Semantychni osoblyvosti interiektyviv". Studia Methodologica, iss. 13, 2003, pp. 26-33.

Krainii, Ivan. "Interviu z S. Pushykom”. Ukraina moloda, iss. 106, www.umoloda.kiev.ua/ number/936/164/34070.

Matsko, Liubov. Interiektyvy v ukrainskii movi. Kyiv, 1981.

Matsko, Liubov. Stylistychni funktsii emotsiinykh vyhukiv. kulturamovy.univ.kiev.ua/KM/ pdfs/Magazine21-5.pdf.

Melnik, Olena. "Primary Interjections as the Object of the Linguistic Investigation". Mova $i$ kultura, iss. 16, vol. 5, 2013, pp. 196-204.

Potebnja, Aleksandr. Jestetika i pojetika. Moskva: Iskusstvo, 1976.

Lucien, Tesnière. Osnovy strukturnogo sintaksisa. Moskva: Progress, 1988.

Todor, Olena. Pro diieslivno-vyhukovi formy v ukrainskii movi. kulturamovy.univ.kiev.ua/ $\mathrm{KM} / \mathrm{pdfs} /$ Magazine45-18.pdf.

Ukrainka, Lesia. "Lisova pisnia”. Povne akademichne zibrannia tvoriv. 14 v. V. 3. "Dramatychni tvory". Lutsk, 2021. pp. 241-329.

Chabanenko, Viktor. Stylistyka ekspresyvnykh zasobiv ukrainskoi movy. Zaporizhzhia, 2002.

Shust, Liudmyla. "Vyhuky-bozhinnia yak osoblyvist sakralnoi kultury ukraintsiv". Scientific Herald Yuriy Fedkovych Chernivtsi National University. Series: Romano-Slavonic Discourse, iss. 772, 2016, pp. 156-8. 